\title{
An Analysis of the Process of Drying Fresh Bales
}

\author{
Janez BENEDIČIČ
}

\begin{abstract}
Due to the confirmed positive effects on the fatty acid composition of milk, drying grass fodder is becoming increasingly important in Alpine areas. Using new technological solutions, such as condensation dryers, makes drying possible also in extreme conditions, such as drying completely fresh fodder in bales. The possibility of such extreme drying of completely fresh bales of lucerne has been confirmed by tests on three modern drying systems in two Alpine countries, in Slovenia and Austria. The drying process was identical in all the dryers, with new technological solutions used in the equipment of the condensation dryer for the second test. The results showed that drying lucerne on a sophisticated condensation dryer is possible with properly executed drying procedures and adequate technological equipment. Such drying completely preserves the energy value of fresh lucerne. The use of new technological solutions for the condensation dryer reduces costs by a further $30-33 \%$.
\end{abstract}

Keywords: air; bale drying; condensation dryer; heat pump; lucerne; net energy for lactation; plate heat exchangers

\section{INTRODUCTION}

Grass fodder drying is a relatively widespread practice in Slovenia. The results of a survey on the farms included in milk quality control $(5,198$ farms) showed that silaging is the dominant practice on around $1 / 3$ of the farms, compared to $1 / 3$ of the farms where fodder is dried exclusively or predominantly, and $1 / 3$ where drying and silaging are equally represented [1]. Making hay usually takes place outside. Less than a third of the farmers use drying systems to dry most of their hay [1], which is reflected in the quality of hay. The analyses of hay on farms, conducted between 2000 and 2010 in laboratories in Slovenia, showed that hay contains a mere 5.05 MJ net energy for lactation (NEL) per kilogramme of dry matter, which is $15 \%$ less when compared to grass silage [1]. With proper drying procedures, it is possible to raise the energy value of hay. This is all the more important for high quality hays, such as lucerne hay. The quality of hay depends on the quality of harvested fodder, as well as on the losses and changes of fodder during drying and storing. Drying and drying up on traditional dryers (hayracks, haystacks), ventilation systems with cool or warm air, or on condensation dryers contributes without doubt to a better quality of hay, while drying completely fresh fodder belongs to the most complex drying procedures. Technological advances provide many new solutions, such as condensation dryers in various configurations, including round bale drying. An Austrian study on a sample of over 500 farms showed that less than a third of the farmers $(27.8$ $\%$ ) were drying hay on the ground, with $39 \%$ using cool air ventilation and $33.2 \%$ warm air ventilation [3]. On 6.3 $\%$ of all the farms where hay is dried up by means of drying systems, they do it in round bales. The results of the analyses showed that in Austria, the dried up hay is of significantly better quality, compared to that dried on the ground. The differences are particularly striking for the first harvest, where the ground-dried hay contained an average of $5.32 \mathrm{MJ}$ of NEL per kg of dry matter, compared to $5.52 \mathrm{MJ}$ of cool air-ventilated hay and 5.74 MJ of warm air-ventilated hay. The differences are believed to be down to the loss of quality parts of the plants due to crushing during turning, collecting and picking the fodder, which can amount to $30 \%$ [2].
The only method to preserve as much NEL per $\mathrm{kg}$ of dry matter as possible is to store the fodder as quickly as possible. This is only possible with the use of warm air ventilation, which requires a lot of energy. For warm air ventilation, $57.2 \%$ of farmers use solar energy, $17.3 \%$ use air dehumidification by means of heat pumps, $12.3 \%$ heat the air with wood chips and $9.1 \%$ with gas oil [3]. On large farms, warming the air is also economical and feasible with the use of dehydrators and heat from biogas facilities, especially for drying lucerne. For drying systems on small and medium-sized farms, typical of Slovenia and other mountain regions in Europe, such source of energy is required that will be suitable and feasible in terms of both costs and technology. One of the better options includes a condensation dryer - dehumidifying the drying air. The use of a condensation dryer is also suitable for drying in extreme cases, such as drying completely fresh bales [4]. It means that cutting the grass is immediately followed by baling, its transportation to the drying facility and the drying procedure. This prevents crushing due to mechanical processing on the grassland or in the field, and it also requires less working operations. A relatively high water content that needs to be extracted from plants during drying poses a major challenge. At $85 \%$ humidity, 4000 $\mathrm{kg}$ of water needs to be extracted in order to produce 1000 $\mathrm{kg}$ of dry hay with the remaining humidity of $15 \%$ [5]. The existing condensation dryer system allows drying fresh bales, however it uses a lot of energy. New technological solutions should reduce energy consumption for drying and improve the efficiency of the fresh bale drying system.

\section{MATERIAL AND METHODS}

\subsection{The Basic Principle of Fodder Drying}

The basic principle of fodder drying is based on the evaporation of water from plants, without feeding heat at the same time. The energy, required for evaporation is extracted from the surrounding air, i.e. the air travelling through fodder / bales, which cools down the air. Because this is an adiabatic process, it is referred to as adiabatic cooling, and in the case of drying it is adiabatic moisturising (Fig. 1). The change is marked with the red line, from point 1 to point 2 . 


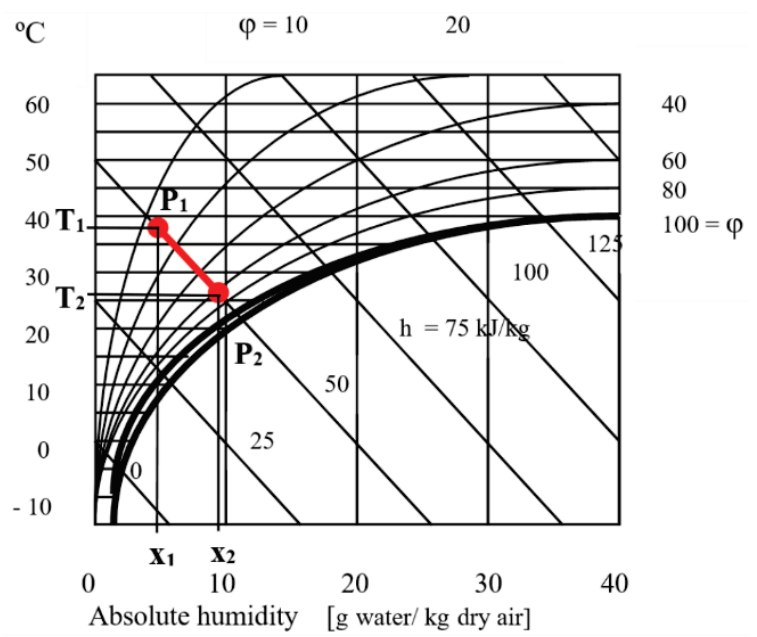

Figure $1 h-x$ diagram with adiabatic process from point 1 (P1) to point 2 (P2)

During the adiabatic process [6] of fodder drying from point P1 to P2 (Fig. 1), air cools down from temperature $T_{1}$ to temperature $T_{2}$ while passing through fodder. Fodder dries, air saturation (absolute humidity) increases from $x_{1}$ to $x_{2}$. In the adiabatic change, the following is true: Enthalpy is constant $h=$ const.

$h_{1}=h_{2}$

$h_{y}=c_{p, L} \cdot T_{y}+x_{y} \cdot\left(r_{0}+c_{p, D} \cdot T_{y}\right)$

$h_{y}$ - enthalpy at a specific point $\left(h_{1}, h_{2}\right)(\mathrm{kJ} / \mathrm{kg})$

$c_{p, L}$ - specific heat of dry air $(\mathrm{kJ} / \mathrm{kgK})$

$c_{p, D}$ - specific heat of water vapour $(\mathrm{kJ} / \mathrm{kgK})$

$r_{0}$ - specific evaporating heat $(\mathrm{kJ} / \mathrm{kgK})$

$x_{y}$ - absolute air humidity $(\mathrm{kg}$ water $/ \mathrm{kg}$ air) at a specific point $\left(x_{1}, x_{2}\right)$

$T_{y}$ - air temperature at a specific point $\left(T_{1}, T_{2}\right)(\mathrm{K})$.

No heat is released or absorbed:

$\Delta Q=0$

The work equals the change in the internal energy:

$A=\Delta W n$

Below are shown the calculation of a maximum theoretical drying capacity (Eq. (7)), a maximum required air temperature for drying (Eq. (10)), and the estimated drying time (Eq. (11)). The Mollier $h-x$ diagram for humid air shows that $0.39 \mathrm{~g}$ of water that moisturises $1 \mathrm{~kg}$ of air cools it down by $1{ }^{\circ} \mathrm{C}$ [7]. This means that a theoretical drying capacity (extracted water from fodder) depends on the difference between the inlet and outlet temperatures of the air that dries fodder. Using the assumption of drying capacity $\Delta x$, a theoretical difference between temperatures in the adiabatic process is first calculated (Eq. (6)).

$$
\Delta T=\frac{\Delta x}{x_{h-x}}
$$

$\Delta T$ - theoretical difference between temperatures in the adiabatic process for extracting a target amount of water $\Delta x(\mathrm{~K})$
$\Delta x$ - drying capacity - a target amount of water, extracted from fodder at $1 \mathrm{~kg}$ of air passing through fodder $(\mathrm{kg}$ water $/ \mathrm{kg}$ air)

$x_{h-x}-0,39 \mathrm{~g}$ water $/ \mathrm{kg}$ air $/ 1{ }^{\circ} \mathrm{C}=0,00039 \mathrm{~kg}$ water $/ \mathrm{kg}$ air $/$ $1{ }^{\circ} \mathrm{C}$

Maximum theoretical capacity water extraction from fodder - $X_{\max }(\mathrm{kg} / \mathrm{h})$ using Eq. (7).

$$
X_{\max }=\Delta x \cdot M
$$

$\mathrm{M}$ - mass air flow $(\mathrm{kg} / \mathrm{h})$

The air entering fodder should have a low enough absolute humidity in order to prevent air saturation during drying, while the air is still inside fodder. It is advisable to feed heat to the inlet air (Eq. (8)):

$Q_{D}=Q_{x}+Q_{l o s}$

$Q_{D}$ - required drying heat input

$Q_{x}$ - required heat input for extracting a target amount of water in the adiabatic drying

$Q_{\text {los }}$ - heat loss during the entire drying process.

$Q_{x}=m_{a} \cdot\left(c_{p, L}+x_{k} \cdot c_{p, D}\right) \cdot \Delta T$

$m_{a}$ - air mass passing through fodder

$x_{2}$ - absolute humidity in drying chamber $=$ absolute humidity at point 2 of the adiabatic process.

Eq. (10) is used to calculate a maximum required air temperature for drying. Losses and needs of the adiabatic process are taken account of.

$T_{c}=\frac{\frac{Q_{x}+Q_{l o s}}{m_{a}}+T_{2} \cdot\left(c_{p, L}+c_{p, D} \cdot x_{2}\right)}{\left(c_{p, L}+c_{p, D} \cdot x_{2}\right)}$

Where the following is always true: $T_{c} \geq T_{1}>T_{2}$.

Drying time $t(\mathrm{~h})$ :

$t=\frac{m_{r b}}{x_{\max }}$

$m_{r b}$ - mass of a fresh round bale / fodder to be dried $(\mathrm{kg})$

However, the properties of plants need to be taken into consideration, too. At the beginning, water is in the intercellular space, and is extracted from the plant at a faster rate. When it needs to cross cell walls, the process is slower. Another factor is the structure of plants, made up of leaves and stalks. Leaves dry faster than stalks due to their larger surface.

\subsection{Basic Operation of a Condensation Dryer}

The main parts of a condensation dryer (Fig. 2) include a fan, a heat pump, air ducts to the bales and a chamber 
where bales are stored. Fig. 3 shows schematic representation of a condensation dryer. The main dryer elements are connected into a drying circuit (Fig. 3). The fan injects warm and dry air into the ducts. It moves along the ducts and then through the bales. The humid air, coming out of the bales, is then sucked through the heat pump where it is dehumidified and warmed again, which is referred to as the closed-circuit drying method (Fig. 3).

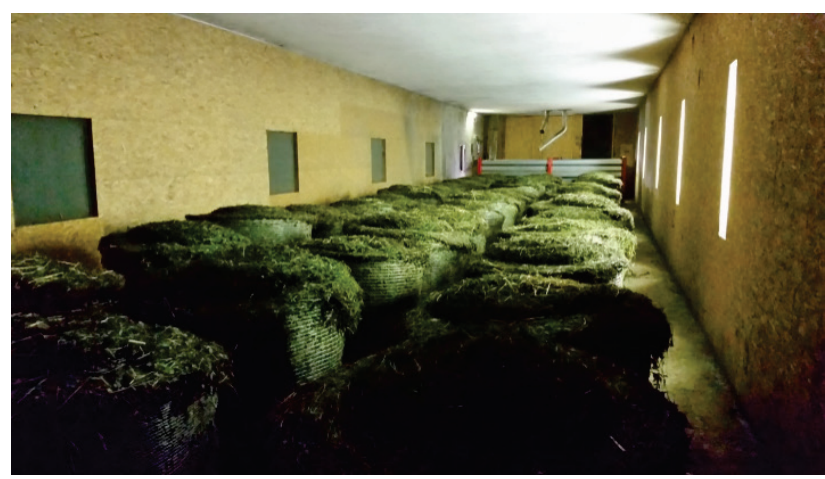

Figure 2 Condensation dryer for the third test

This drying method is also to a larger extent independent of the outside weather and conditions. The biggest external impact on the operation is the external temperature and losses through the drying facility structure, which partly affects the temperature regime of operation. With higher external temperature, the system operates at higher temperatures; if it is lower, it operates at lower temperatures. In the case of high external temperatures, the system can of course operate in an open circuit - it sucks the ambient air, dehumidifies it, heats it up and injects it into the bales. The air is released from the drying chamber into the environment.

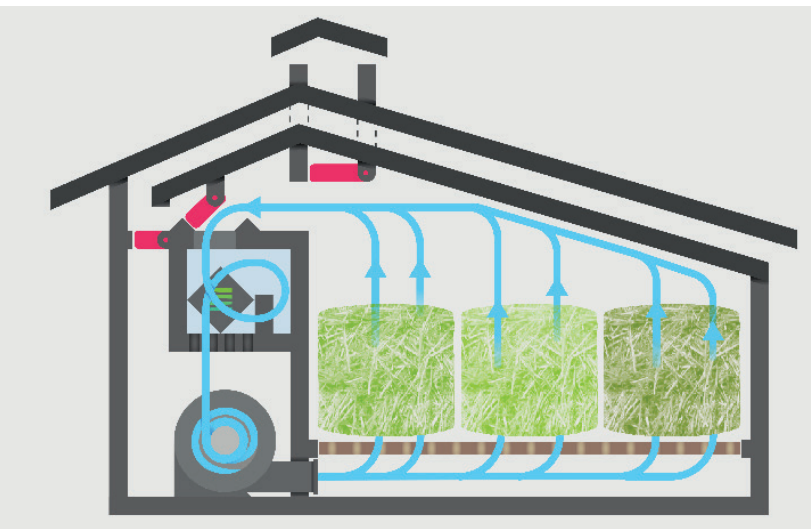

Figure 3 Schematic representation of a condensation dryer, showing a closedcircuit operation.

The heat pump, the key element of a condensation dryer, basically consists of an evaporator, a compressor and a condenser. A heat pump's function is to dehumidify the air on the evaporator and then heating up the same air on the condenser [5]. The energy, extracted on the evaporator, is transformed into the energy, supplied to the air on the condenser.

\subsection{New Technological Solution for the Heat Pump}

The demand for ever-increasing performance of heat pumps and extreme weather situations (rain periods) acted as a catalyst for tests in the area of drying completely fresh fodder in a condensation dryer. The key function of a heat pump in a condensation dryer is extracting water - drying air. Observing the operation parameters of a bale-drying condensation dryer showed that relative exit humidity in the drying chamber drops already during the first 12 hours of drying [4]. The bale core dries first, and more air passes through it; the air is dry, less saturated with moisture. The core is followed by the upper and the lower edges. A thermal camera view supports this (Fig. 4). With the air coming out of the fodder less saturated, it makes drying less efficient. The existing heat pump system (Fig. 5) is efficient in the initial drying phase, when the exit air in the drying chamber has a higher relative humidity (above 70 $\%$ ), while its efficiency is dropping together with lower relative humidity of the exit air in the drying chamber. This was the reason to upgrade it with plate heat exchangers, which improves drying efficiency. Plate heat exchangers are those that make it possible to transfer heat between two airflows operating at different temperatures.

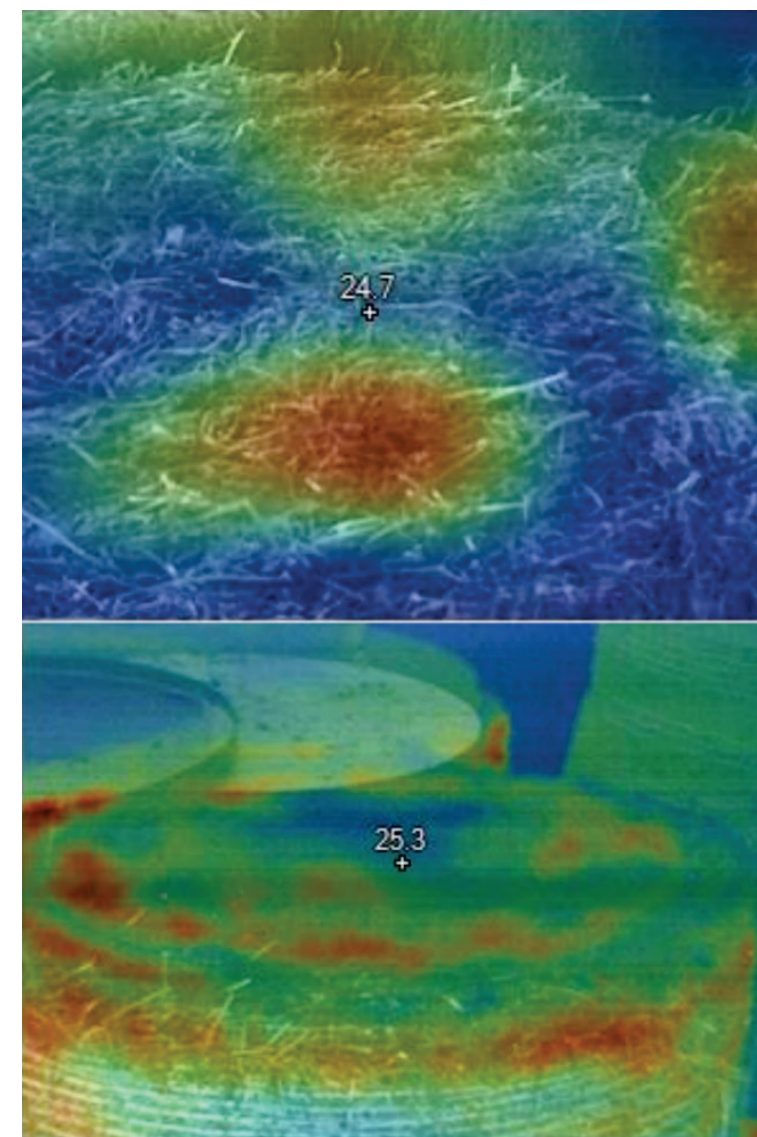

Figure 4 Thermal camera view of a bale during drying (above: leaking of warm and less saturated air through the core; below: leaking on the edges and on the edge of the lid).

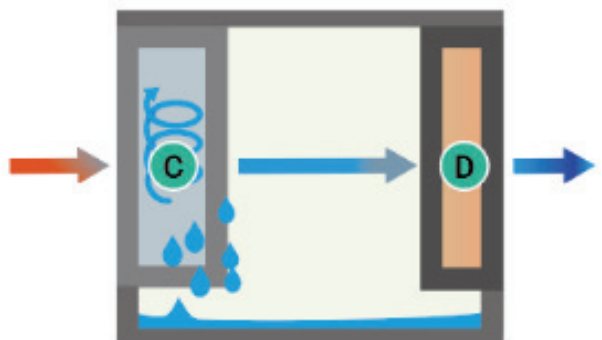

Figure 5 The existing heat pump system ( $\mathrm{C}$ - evaporator, $\mathrm{D}$ - condenser) 
An air-to-air plate heat exchanger (marked with B in Fig. 6) was installed into the systems between the inlet (Fig. 6-mark A), the evaporator (Fig. 6-mark C) and the condenser (Fig. 6 - mark D). Airflow through the heat pump is marked with an arrow in Figure 6. Air flows into the heat pump from the drying chamber. First, it enters the plate heat exchanger through the first inlet, where it releases part of the heat. It reduces the temperature and increases relative humidity of the air that is then travelling to the evaporator, which has a favourable effect on the efficiency of the evaporator where water is being extracted. It makes water extraction more efficient throughout the drying process. Part of the water (up to $5 \%$ of total water content at the inlet air humidity of above $90 \%$ ) is extracted also through the plate heat exchanger. From the evaporator, air travels in a semi-circular direction to the other plate heat exchanger inlet, where it receives the added heat of the input air. It heats up to its final temperature on its way through the condenser. When leaving the heat pump, the air is heated and dry.

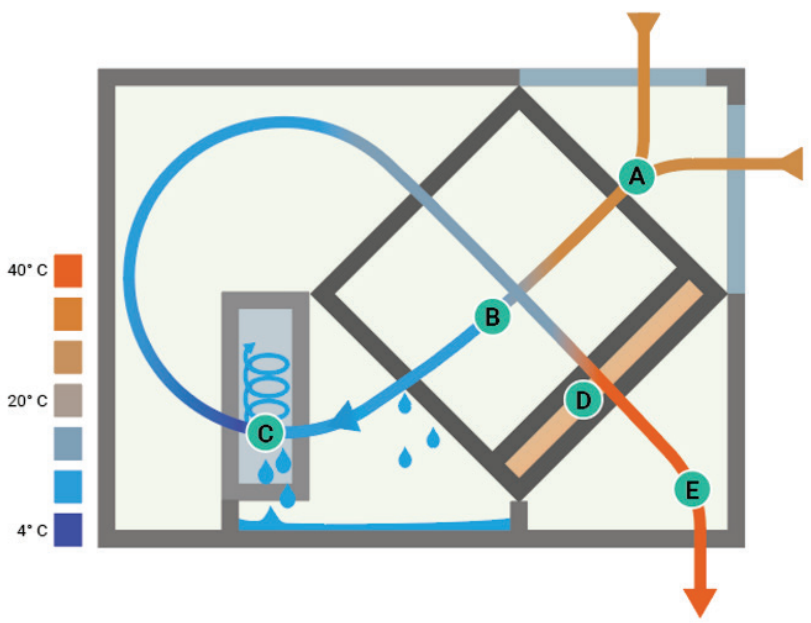

Figure 6 New technological solution for the heat pump ( $A$ - heat pump air intake, $\mathrm{B}$ - plate heat exchanger, $\mathrm{C}$ - evaporator, $\mathrm{D}$ - condenser, $\mathrm{E}$ - heat pump air outlet).

\subsection{Drying Process and New Technological Solutions for the Drying Process}

Drying completely fresh fodder is very demanding, from the viewpoints of both keeping adequate air flow, and the heat pump operation. Any error in drying or making bales is reflected in prolonged drying and damp pockets that can remain inside a bale after drying. Drying intensity is not steady throughout the drying period. It is the highest at the beginning, when relative humidity of the outlet air, exiting the bale, is also at its highest and can exceed $90 \%$. The drying process ends at a low relative humidity of the outlet air, which can drop below $30 \%$. The fastest drop in outlet relative humidity can be observed during the first 20 hours [4], after which the intensity of relative decrease in humidity gradually slows down. Channels are being formed inside the bale, through which air penetrates to the surface of the bale. These channels increase with drying, which increases the volume of less saturated air that leaves the bale, making the outlet air increasingly dry (of lower humidity), and the efficiency of drying decreases. Adequate air flow is the basic drying parameter, as air represents the transport system for extracting water from fodder. Air flow of between $1100 \mathrm{~m}^{3} / \mathrm{h} /$ bale and 1500 $\mathrm{m}^{3} / \mathrm{h} /$ bale $[7,8]$ is required. The required fan power depends on the flow and static pressure that a fan should provide, which in turn depends on the resistance created at the passage of a certain volume of air through fodder/bale. Resistance depends on witherness and fodder density inside the bale [8]. In the literature [8], the value of the required static pressure is up to $1400 \mathrm{~Pa}$, however, test drying of fresh fodder in bales showed that this value is too low.

As a result, an important technological solution for the condensation dryer includes controlled air flow. This can be achieved by means of fan speed frequency control and air flow measuring. The fan should be capable of providing optimum drying also in critical conditions, which is definitely true in the case of fresh bales. When air flow is too high, it can be reduced and drying becomes more economical.

\subsection{Test Parameters}

The main objective of the test was to judge the feasibility of drying fresh lucerne in bales on small and large condensation dryers, energy consumption for drying and the effect of new technological solutions on drying and energy consumption for drying. In each test, bales were weighed before and after drying, which yielded an amount of dry matter, dried in each of the tests. Monitored were also drying time, heat pump and fan consumption of electricity, and in the second test also the required fan power. On the basis of the measured parameters, the drying parameter will also be calculated. It will be presented on the form of energy consumption per $1 \mathrm{~kg}$ DM and in the form of extracted water $1 \mathrm{kWh}$ of energy consumed

\subsection{Testing}

Drying fodder - lucerne took place in a condensation dryer (Fig. 2) for round bales with a diameter of $125 \mathrm{~cm}$ (first and second test) and in a dryer for round bales with a diameter of $135 \mathrm{~cm}$ (third test). The first and the second test were performed in Slovenia, and the third in Austria (Fig. 7). The first test was performed in a regular condensation dryer with a capacity of 6 bales, the second one in the same dryer, with its equipment upgraded with new technological solutions, such as an improved heat pump with plate heat exchangers, a high static pressure fan ( $\max 4000 \mathrm{~Pa}$ ), a frequency inverter to control fan speed, and air flow measuring. In terms of technical sophistication, the condensation dryer for the third test was identical to the dryer in the first test. Tab. 1 shows the capacities of each dryer.

Table 1 Capacities of condensation dryers where tests took place

\begin{tabular}{|l|c|c|c|}
\hline & $\begin{array}{c}\text { First } \\
\text { test dryer }\end{array}$ & $\begin{array}{c}\text { Second } \\
\text { test dryer }\end{array}$ & $\begin{array}{c}\text { Third } \\
\text { test dryer }\end{array}$ \\
\hline Fan power & $5.5 \mathrm{~kW}$ & $\begin{array}{c}15 \mathrm{~kW} \text { with } \\
\text { frequency inverter }\end{array}$ & $3 \times 15 \mathrm{~kW}$ \\
\hline $\begin{array}{l}\text { Fan air flow at } \\
\text { the test }(\mathrm{kg} / \mathrm{h})\end{array}$ & 8.669 & 7.224 & 65.021 \\
\hline $\begin{array}{l}\text { Heat pump } \\
\text { power }\end{array}$ & $12 \mathrm{~kW}$ & $\begin{array}{c}12 \mathrm{~kW}+\text { plate } \\
\text { heat exchanger }\end{array}$ & $3 \times 22 \mathrm{~kW}$ \\
\hline No. of bales & $\begin{array}{c}2 \times 3 \text { bales }=6 \\
\text { bales }\end{array}$ & $\begin{array}{c}2 \times 3 \text { bales }=6 \\
\text { bales }\end{array}$ & $\begin{array}{c}3 \times 15 \text { bales }= \\
45 \text { bales }\end{array}$ \\
\hline
\end{tabular}


For test runs, it is important how the bales are made. Improperly made bales can cause damp pockets during bale drying. We opted for softcore bales. The bales for the first test were made using a Krone-manufactured fixed chamber baler, for the second one a John Deere semi-variable chamber baler and for the third test a Kuhn variable chamber baler.

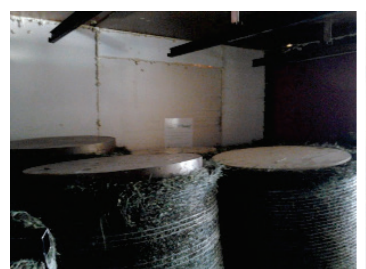

Figure 7 Condensation dryer for bale drying (left: first and second test; right: third test)

\section{$3 \quad$ RESULTS AND DISCUSSION}

Fresh bales of the first test had a mean mass of $520 \mathrm{~kg}$ after baling, compared to between $90 \mathrm{~kg}$ and $105 \mathrm{~kg}$ after drying, which means that around $400 \mathrm{~kg}$ of water per 100 $\mathrm{kg}$ of lucerne hay had to be extracted.

Using theoretical assumptions and equations, a theoretical amount of extracted water was calculated and compared to the actual amount of extracted water (Tab. 2). Theoretical calculation showed more economical drying in the second test - identical to the executed tests. A significant difference between the actually extracted water and theoretical calculation can be attributed to the loss of heat into the environment and lower drying efficiency in the second part of drying. Part of a bale is already dry and in these spots air leaves the bale less saturated. The efficiency of the heat pump decreases as less humid air enters its evaporator. Here, an advantage of new technological solutions to the heat pump from the second test is demonstrated. It is more efficient even with the inlet air of lower humidity, which also results in a smaller difference between the theoretical calculation and test results in Tab. 2. Compared to actual results, $35 \%$ and 32 $\%$ more water can be theoretically extracted in the first and the third test, respectively. In the second test, the difference was $11 \%$.

Table 2 Theoretical vs. test results.

\begin{tabular}{|l|r|r|r|}
\hline & $\begin{array}{c}\text { First } \\
\text { test }\end{array}$ & $\begin{array}{c}\text { Second } \\
\text { test }\end{array}$ & $\begin{array}{c}\text { Third } \\
\text { test }\end{array}$ \\
\hline $\begin{array}{l}\text { Total DM (dry matter) mass of bales after } \\
\text { drying (kg) }\end{array}$ & 555 & 732 & 7.515 \\
\hline Extracted water (total) - test (kg) & 2.220 & 2.649 & 30.068 \\
\hline Drying time (h) & 75 & 64 & 144 \\
\hline Extracted water (total) - theoretical (kg) & 3.423 & 2.975 & 43.819 \\
\hline $\begin{array}{l}\text { Difference in the extracted water between } \\
\text { the theoretical value and the test (\%) }\end{array}$ & 35,1 & 10,9 & 31,3 \\
\hline
\end{tabular}

Compared to the first test, bale density for the second and third test was significantly higher due to the use of a variable and a semi-variable baler, where core pressure can be controlled, which is not possible with a fixed chamber. It also affected the drying efficiency. Tab. 3 shows that new technological solutions to the equipment and drying process improve the drying efficiency. The drying efficiency is measured in the form of two parameters: the energy consumption per dried mass of the fodder and the amount of water extracted per unit of energy consumed. Drying on a condensation dryer with new technological solutions required $1.49 \mathrm{kWh} / \mathrm{kg}$ of $\mathrm{DM}$, compared to between 2.15 and $2.22 \mathrm{kWh} / \mathrm{kg}$ of DM in tests on regular condensation dryers. The second parameter for measuring the drying efficiency also showed that drying with a technically improved dryer (second test) was more effective (Fig. 8). We extract 2,34 kg of water per $1 \mathrm{kWh}$ consumed energy. In the first and third tests, only 1.81 and $1.88 \mathrm{~kg}$ of water were extracted per $1 \mathrm{kwh}$ of energy consumed (Tab. 3) (Fig. 8). It is believed that lower energy consumption for drying can be attributed to more efficient operation of the heat pump, equipped with a crossflow exchanger and controlled air flow through bales. Despite having $15 \mathrm{~kW}$ of fan power available for the second test, the average power was between $5 \mathrm{~kW}$ and $7 \mathrm{~kW}$, thanks to controlled air flow, while in the first and third test, fans were operating at full power. The first fan operates with capacity of $8.669 \mathrm{~kg} / \mathrm{h}$, the second with $7.224 \mathrm{~kg} / \mathrm{h}$ and the third with $65.021 \mathrm{~kg} / \mathrm{h}$ of air. The first test drying took 75 hours, the second one 64 hours and the third one 144 hours. A more powerful heat pump could further reduce drying time.

\begin{tabular}{|l|r|r|r|}
\hline \multicolumn{1}{|c|}{ Table 3 Capacities of condensation dryers where tests took place. } \\
\hline & $\begin{array}{c}\text { First } \\
\text { test }\end{array}$ & $\begin{array}{c}\text { Second } \\
\text { test }\end{array}$ & $\begin{array}{c}\text { Third } \\
\text { test }\end{array}$ \\
\hline $\begin{array}{l}\text { Total DM (dry matter) mass of bales } \\
\text { after drying (kg) }\end{array}$ & 555 & 757 & 7.515 \\
\hline Mean density of dry bale (kg DM/m $\left.{ }^{3}\right)$ & 75 & 123 & 116,8 \\
\hline $\begin{array}{l}\text { Electric power consumption for drying } \\
\text { (kWh) }\end{array}$ & 1.230 & 1.128 & 15.984 \\
\hline Used energy (kWh/kg DM) & 2,22 & 1,49 & 2,12 \\
\hline $\begin{array}{l}\text { Extracted water per consumed energy } \\
\text { (kg water/kWh) }\end{array}$ & 1,81 & 2,34 & 1,88 \\
\hline
\end{tabular}

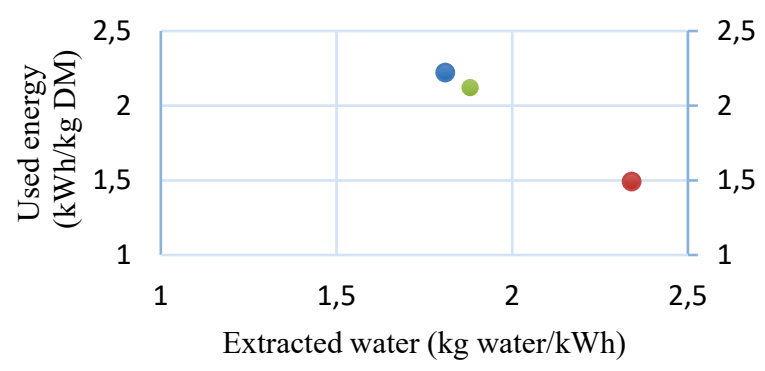

First test $\quad$ Second test test

Figure 8 Comparison between the amount of water extracted per unit of energy and the energy consumed per unit of dry matter for all three tests.

\section{CONCLUSION}

If was found that drying completely fresh lucerne bales in a condensation dryer is possible. Monitoring energy consumption revealed that new technological solutions contribute to the reduction of power consumption for drying. It was reduced by $30-33 \%$. A controlled air flow system improves fan economy, and allows drying the bales of higher density. Drying fresh lucerne in bales is technically possible and economically feasible. An accurate assessment would need to take account of a cost analysis of working operations on the grassland and at the drying facility during drying withered and unwithered lucerne, as well as dry matter loss due to additional 
working operations. The test showed that drying fresh lucerne bales is feasible in both small ( 6 bales) and large (45 bales) condensation dryers.

Grass fodder drying is a complex process as all parameters such as fodder humidity, ambient temperature and humidity, temperature and humidity in the process vary during the drying process. The ability to transfer water from the plant to the air has been found to be crucial and will be further investigated.

\section{REFERENCES}

[1] Verbič J., Babnik D., Jeretina J., \& Perpar T. (2006). Navade rejcev pri krmljenju krav v Sloveniji in njihov vpliv na mlečnost, sestavo mleka in zdravstveno stanje. $V$ : Zbornik predavanj 15. posvetovanja o prehrani domačih živali "Zadravčevi-Erjavčevi dnevi". Kapun, S. (ur.), Čeh, T. (ur.). Murska Sobota, Kmetijsko gozdarska zbornica Slovenije in Kmetijsko gozdarski zavod Murska Sobota, 119-135.

[2] Frick, R., Ammann, H., Wyss, U., \& Daccord, R. (1999) Einsatz von Intensivaufbereitern in der Futterwerbung. FAT Berichte, 532, Tänikon, Eidgenössische Forschungsanstalt für Agrarwirtschaft und Landtechnik, p. 20.

[3] Resch, R., Buchgraber, K., Wiedner, G., Frank, P., Meusburger, C., Pichler, M., Stromberger, W., Tiefenthaller, F., \& Wurm, K. Praxisheu. (2011). Raufutterqualität auf österreichischen Betrieben. Irdning, Lehr- und Forschungszentrum für Landwirtschaft RaumbergGumpenstein, p. 56.

[4] Benedičič, J. \& Verbič, J. (2013). Sušenje lucerne s kondenzacijsko sušilnico $=$ Alfalfa drying by the use of condensation dryer. V: Čeh, Tatjana (ur.), Kapun, Stanko (ur.). Proceedings of the $22^{\text {nd }}$ International Scientific Symposium on Nutrition of Farm Animals: ZadravecErjavec Days 2013, Radenci, $14^{\text {th }}$ and $15^{\text {th }}$ November 2013. Murska Sobota: Kmetijsko gozdarska zbornica Slovenije, Kmetijsko gozdarski zavod, str. 67-71.

[5] Weingartmann, H. (April 2002). Technik und Perspektiven in der Heutrocknung. 8. Alpenländisches Expertenforum. Bundesanstalt für alpenländische Landwirtschaft Gumpenstein, Irdning.

[6] Rant, Z. (2011). Termodinamika, Fakulteta za strojništvo, Univerza v Ljubljani

[7] Wirleitner, G. (2011). Energieefficienter Heutrocknungstechnik 2011, Heugala 2011, Bundesanstalt für alpenländische Landwirtschaft Gumpenstein.

[8] Wirleitner, G. (2013). Neue Dimensionen in der Rundballentrocknung. Bautagung Raumberg - Gumpenstein 2013, Raumberg Gumpenstein.

\section{Contact information:}

Janez BENEDIČIČ, PhD, Assistant Professor

Laboratory LECAD,

Faculty of Mechanical Engineering,

University of Ljubljana,

Aškerčeva 6, SI-1000 Ljubljana, Slovenia

janez.benedicic@lecad.fs.uni-lj.si 